\title{
PENINGKATAN KECERDASAN VISUAL SPASIAL MELALUI BERMAIN MIND MAPPING
}

\author{
(Penelitian Tindakan di Kelompok Raudhatul Athfaal Mardhati, \\ Makassar, 2017)
}

\author{
FADHILAH LATIEF \\ PG-PAUD UNIVERSITAS MUHAMMADIYAH MAKASSAR
}

\begin{abstract}
The objectives of this research is to improve the visual-spatial intelligence of children through playing mind mapping. This research was carried out in group Raudhatul Athfaal Mardhati, Makassar with 13 subject, on the month from April to May 2017. This research uses an action research design model of Kemmis and Mc Taggart, through two cycles consisting of seven meetings on the first cycle and six meetings on the second cycle which includes the stages of planning, action, observation and reflection. Data analysis using quantitative and qualitative analysis. Data obtained by referring to the research instrument which refers to the visual-spatial intelligence. The results showed an increase in visual-spatial intelligence scores of children with the acquisition of visual-spatial intelligence classical pre-action reached $49.25 \%$, the first cycle increased the score reached $75.15 \%$ and the second cycle was obtained which satisfy the classical score reached $88.28 \%$ so it can be concluded that the activity playing mind mapping can improve children's visual-spatial intelligence.
\end{abstract}

Key Words: visual-spatial intelligence, playing mind mapping, action research

\begin{abstract}
Abstrak : Penelitian ini bertujuan untuk meningkatkan kecerdasan visual spasial anak melalui bermain mind mapping. Penelitian ini dilaksanakan di kelompok Raudhatul Athfaal Mardhati Kota Makassar dengan 13 orang anak. Penelitian dilaksanakan pada bulan April sampai Mei 2017. Penelitian ini menggunakan rancangan penelitian tindakan dengan model Kemmis dan Mc Taggart, melalui dua siklus yang terdiri dari tujuh pertemuan pada siklus I dan enam kali pertemuan pada siklus II yang meliputi tahap perencanaan, tindakan, observasi dan refleksi. Analisis data menggunakan analisis kuantitatif dan kualitatif. Data diperoleh dengan berpedoman pada instrumen penelitian yang mengacu pada aspek kecerdasan visual spasial. Hasil penelitian menunjukkan adanya peningkatan kecerdasan visual spasial anak dengan perolehan skor klasikal pada pra tindakan mencapai $49.25 \%$, siklus I mengalami peningkatan skor mencapai $75.15 \%$, dan pada siklus II diperoleh skor klasikal yang memuaskan mencapai $88.28 \%$ sehingga dapat disimpulkan bahwa bermain mind mapping dapat meningkatkan kecerdasan visual spasial anak.
\end{abstract}

Kata Kunci : kecerdasan visual spasial, mind mapping, penelitian tindakan. 


\section{Pendahuluan}

Masa usia dini merupakan masa yang sangat menentukan bagi perkembangan dan pertumbuhan anak selanjutnya karena merupakan masa peka dan masa emas dalam kehidupan anak. Hal ini mengisyaratkan bahwa semua pihak perlu memahami akan pentingnya masa usia dini untuk optimalisasi pertumbuhan dan perkembangan. Usia lahir sampai dengan memasuki pendidikan dasar merupakan masa keemasan sekaligus masa kritis dalam tahapan kehidupan manusia, yang akan menentukan perkembangan anak selanjutnya. Masa tersebut adalah masa yang tepat untuk meletakkan dasar-dasar pengembangan kemampuan fisik, kemandirian, pengembangan bahasa, kognitif, sosial-emosional, konsep diri, seni, moral, nilai-nilai agama, termasuk pengembangan kecerdasan jamak anak.

Salah satu dari kecerdasan tersebut adalah kecerdasan visual spasial yang menyangkut kemampuan seseorang dalam mempersepsikan sesuatu secara visual, kemampuan untuk melihat secara detail, dan dengan kemampuan ini dapat melihat segala objek yang diamati. Kecerdasan visual spasial sangat dibutuhkan anak ketika belajar, terutama ketika anak diperkenalkan dengan bentukbentuk huruf dan bentuk angka. Kecerdasan visual spasial merupakan salah satu aspek dari kognitif yang digunakan untuk memvisualisasikan gambar didalam pikiran seseorang. Anak dengan kecerdasan visual spasial akan kepekaan terhadap bentuk, simbol, garis, warna, keseimbangan, pola dan hubungan antar unsur tersebut. Kecerdasan ini digunakan anak untuk berfikir dalam bentuk visualisasi dan gambar untuk memecahkan masalah atau menemukan jawaban.

Salah satu stimulasi visual yang dapat mengembangkan kecerdasan visual spasial yakni melalui metode bermain mind mapping. Mind mapping atau pemetaan pikiran telah menjadi salah satu metode visualisasi pengetahuan secara grafis untuk mengoptimalkan eksplorasi seluruh area kemampuan otak. Pada permainan mind mapping ini tidak hanya sekedar melatih 
kemampuan menggambar, mewarnai, membentuk garis, melainkan dapat pula untuk melatih anak dalam mengenalkan bentuk simbol huruf, kata, mengenal lambang angka, dan melatih ingatan anak. Selain itu, dapat mengembangkan otak kiri dan otak kanan anak sesuai dengan tahapan perkembangannya. Sehingga dengan permainan ini dapat membantu anak dengan cepat dan efektif dalam mengenali bentuk simbol huruf dan simbol angka.

Hal tersebut senada dengan sebuah hasil penelitian yang menunjukkan bahwa penerapan metode mind mapping berbantuan media kartu gambar dapat meningkatkan kemampuan bahasa anak TK pada kelompok A semester II di TK Hindu Widya Kerthi Denpasar tahun ajaran 2012/2013. Hal ini dapat dilihat dari adanya peningkatan kemampuan bahasa pada setiap siklus. Berdasarkan pelaksanaan pembelajaran siklus I, dapat diketahui pencapaian kemampuan bahasa sebesar 52,30\% menjadi sebesar $91,10 \%$ pada siklus II yang berada pada kategori sangat aktif. Hasil penelitian di atas menjadi dasar bahwa metode mind mapping dapat menjadi metode yang mampu meningkatkan kemampuan berbahasa anak usia TK.

Berdasarkan hasil pengamatan pada sebuah lembaga pendidikan formal yakni kelompok Raudhatul Athfaal Mardhati di kota Makassar, Provinsi Sulawesi Selatan. Di sekolah tersebut saat pembelajaran berlangsung, guru memberikan pengajaran mengenai pengenalan huruf, terlihat beberapa anak masih kesulitan dan bingung dalam mengenali dan cenderung masih kurang tepat dalam menyebutkan bentuk simbol huruf, simbol angka, ada pula beberapa anak yang masih kurang tepat dalam menyebutkan jenis warna yang ditanyakan guru. Adapun hasil wawancara dengan pihak guru yang menunjukkan bahwa dari 20 siswa ada 13 anak usia 5-6 tahun di kelompok RA yang masih lemah dalam mengenali simbol huruf dan simbol angka. Secara umum ketigabelas anak tersebut masih rendah dalam kecerdasan visual spasialnya. Selain itu, guru tersebut 
menjelaskan bahwa penyajian pengenalan huruf dan angka kepada anak masih dilakukan dengan cara menggunakan flash card, poster dan terkadang juga guru menuliskan di papan tulis, namun hal tersebut belum efektif dalam meningkatkan kecerdasan visual spasial anak.

\section{Fokus Penelitian}

Fokus penelitian ini adalah upaya peningkatan kecerdasan visual spasial melalui bermain mind mapping pada anak usia 5-6 tahun di RA (Raudhatul Athfaal) Mardhati Kota Makassar. Kecerdasan visual spasial yang dimaksudkan dalam penelitian ini yakni berfokus pada pengenalan konsep objek visual berupa bentuk simbol huruf dan simbol/lambang angka, kepekaan terhadap warna dan gambar.

\section{Rumusan masalah}

Berdasarkan latar belakang masalah dan fokus penelitian di atas, perumusan masalah dalam penelitian ini adalah sebagai berikut:

1. Bagaimana proses kegiatan bermain mind mapping dalam meningkatkan kecerdasan visual spasial pada anak usia 5-6 tahun?

2. Apakah terdapat peningkatan kecerdasan visual spasial pada anak usia 5-6 tahun pada kelompok RA (Raudhatul Athfaal) Mardhati Kota Makassar setelah diberi kegiatan bermain mind mapping?

\section{Tujuan Penelitian}

Penelitian tindakan ini bertujuan untuk :

1. Untuk mengetahui proses kegiatan bermain mind mapping dalam meningkatkan kecerdasan visual spasial pada anak.

2. Untuk mengetahui peningkatan kecerdasan visual spasial pada anak usia 5-6 tahun kelompok RA (Raudhatul Athfaal) Mardhati Kota Makassar setelah diberi kegiatan bermain mind mapping.

\section{Kajian Pustaka}

1. Kecerdasan Visual Spasial Anak Usia 5-6 Tahun

Gardner

mengemukakan bahwa, spatial intelligence are the capacities to 
perceive the visual world accurately, to perform transformations and modifications upon one's initial perceptions, and to be able to re-create aspects of one's visual experience, even in the absence of relevant physical stimuli. Pernyataan tersebut memiliki arti bahwasanya kecerdasan visual spasial merupakan kapasitas atau kemampuan untuk mempersepsi dunia visual (bentuk atau objek) secara akurat untuk melakukan transformasi dan modifikasi pada persepsi awal seseorang dan untuk dapat menciptakan kembali aspek pengalaman visual seseorang, walau tanpa adanya rangsangan. Secara garis besar dapat disimpulkan menurut Gardner kecerdasan visual spasial merupakan kemampuan untuk membayangkan dan menghadirkan bentuk maupun tata ruang. Kecerdasan yang mencakup berpikir melalui gambar, serta mampu untuk menyerap, mengubah dan menciptakan kembali berbagai macam bentuk atau wujud.
Sonawat dan Gogri (2008:62) kecerdasan spasial visual merupakan kemampuan yang melibatkan potensi dalam mengenali suatu objek visual, melatih kepekaan terhadap hubungan antara garis, warna, bentuk, dan pola ruang. Hal di atas terkait tentang kemampuan seseorang dalam mempersepsi secara visual suatu objek atau simbol (gambar, huruf, dan angka) yang diamati melalui panca indera khususnya indra mata kemudian mampu diinterpretasikan dalam bentuk konkrit yang tepat melalui media visual seperti bentuk lukisan, sketsa, kolase, permainan peta, puzzle dan sebagainya.

Armstrong (Tadkiroatun, 2008:49) mengemukakan bahwa kecerdasan visual spasial merupakan kepekaan yang dimiliki oleh seseorang terhadap warna, garis-garis, dan bentukbentuk. Lebih lanjut Armstrong menjelaskan bahwa stimulasi cara belajar anak yang mampu meningkatkan kecerdasan visual spasialnya dapat dilakukan melalui teknik membangun, 
mewarnai, mengkombinasikan warna-warna, bermain imajinasi, memetakan pikiran, mencermati bentuk, menggambar dan menyusun.

Dalam hal ini kemampuan seseorang dalam membayangkan sesuatu objek, melahirkan ide secara visual (dalam bentuk gambar atau bentuk yang terlihat oleh indera mata). Anak yang memiliki kecerdasan dalam visual dapat mempergunakan apa pun untuk membentuk sesuatu objek yang bermakna baginya. Berbagai macam stimulasi visual dapat diberikan kepada anak agar dapat membantu dalam menunjang proses pembelajaran yang tepat.

Kemudian menurut Campbell, Campbell dan Dickinson (2002:108) menjelaskan bahwa kecerdasan visual spasial meliputi kumpulan dari kemampuan-kemampuan yang saling berkait termasuk perbedaan visual, pengenalan visual, proyeksi, gambaran mental, pertimbangan ruang, manipulasi gambar, dan duplikasi dari gambaran internal atau hal yang dapat diekspresikan dari gambaran tersebut.

Kemampuan ini memudahkan seseorang dalam memahami sesuatu dalam sebuah gambaran yang jelas. Melalui visualisasi seseorang dapat membayangkan sesuatu hal dan menggabungkannya dengan berbagai kemungkinan penggambaran lainnya, memodifikasi, sehingga kemudian terbentuk gambaran baru. Gambaran baru tersebut kemudian muncul sebagai ide-ide yang kreatif. Karena itulah visualisasi perlu dirangsang dan penggunaan sederhananya dapat dilakukan secara spontan dalam pembelajaran.

Adapun teori yang dikemukakan oleh Prasetyo dan Andriani (2009:57) yang mendefinisikan kecerdasan visual spasial merupakan kapasitas untuk mengenali dan melakukan penggambaran atas objek atau pola yang diterima otak. Hal ini menjadi dasar bahwa kemampuan mengenali objek visual melibatkan aktivitas otak yang 
optimal. Selain itu, melibatkan kemampuan individu dalam mengasah kreativitasnya dalam mengenal objek-objek visual yang ada disekitarnya.

Berdasarkan teori yang telah diuraikan di atas, maka dapat disimpulkan bahwa kecerdasan visual spasial adalah kemampuan individu dalam berpikir secara visual yang terdiri atas kemampuan mempersepsikan objek visual, kepekaan terhadap konsep objek visual, serta kemampuan mengenali persamaan dan perbedaan objek secara visual.

\section{Mind Mapping}

Buzan

(2006:8-9)

menjelaskan pula bahwa mind map merupakan alat berpikir yang sangat efektif karena alat tersebut bekerja dengan otak manusia dan mendorong otak untuk mengembangkan asosiasi antar gagasan. Alat ini menjadi menarik perhatian individu pada apa yang menjadi inti persoalan melalui asosiasi dan imajinasi. Berdasarkan hal tersebut, mind map menjadi sarana manifestasi visual yang dapat membebaskan kecerdasan kreatif dalam diri individu dan melalui mind map, seorang anak diharapkan mampu mengembangkan daya imajinasinya.

Mind mapping adalah sebuah metode visualisasi pengetahuan secara grafis untuk mengoptimalkan eksplorasi seluruh area kemampuan otak. Kegiatan mind mapping adalah kegiatan panca indra khususnya mata yang merekam gambar dan warna, dimana gambar dan warna melibatkan kerja otak kanan, sehingga terjadilah sinergi pada otak kita. (Olivia \& Ariani, 2009: 25\&31). Dalam hal ini metode mind mapping suatu metode yang dapat membentuk pola berpikir seseorang, dan dapat merangsang kedua belahan otak anak secara cepat dan tepat.

Mind mapping mempunyai banyak manfaat dalam penggunaannya, khususnya bagi anak yaitu (1) dapat membantu untuk berkonsentrasi; meningkatkan kecerdasan visual spasial; (3) melatih kemampuan berpikir kritis dan komunikasi; (4) 
membantu mendapatkan atau memunculkan ide; serta membantu menggunakan kedua belahan otak yang membuat seseorang ingin selalu belajar. (Olivia, 2008:8). Salah satu manfaat mind mapping yang dijelaskan di atas yakni dapat meningkatkan kecerdasan visual spasial, maka dengan kegiatan bermain mind mapping ini diharapkan mampu menjadi stimulasi yang efektif, sehingga dapat mengoptimalkan kecerdasan visual spasial anak usia dini.

Berdasarkan teori yang telah diuraikan diatas, maka dapat disimpulkan bahwa mind mapping merupakan aktivitas yang efektif sebagai motede visualisasi dalam melatih daya imajinasi dan kemampuan berpikir kreatif. Kegiatan bermain mind mapping merupakan salah satu kategori bermain kreatif dan imajinatif, menjadi konsep baru dalam memfungsikan aktivitas otak dalam berpikir. Dan menjadi cara baru untuk belajar dan berlatih yang cepat dan ampuh.

\section{Metode Penelitian}

Penelitian ini menggunakan metode penelitian tindakan dengan model Kemmis dan Mc. Taggart melalui dua siklus yang terdiri dari tujuh pertemuan pada siklus I dan enam kali pertemuan pada siklus II yang meliputi tahap perencanaan, tindakan, observasi dan refleksi. Penelitian dilaksanakan pada bulan April sampai Mei 2017. Tempat penelitian di kelompok Raudhatul Athfaal Mardhati Makassar dengan 13 responden.

Penelitian tindakan ini bertujuan untuk mengetahui proses kegiatan bermain mind mapping dalam meningkatkan kecerdasan visual spasial pada anak dan untuk mengetahui peningkatan kecerdasan visual spasial pada anak usia 5-6 tahun kelompok RA (Raudhatul Athfaal) Mardhati Kota Makassar setelah diberi kegiatan bermain mind mapping. Data diperoleh dengan berpedoman pada instrumen penelitian yang mengacu pada aspek kecerdasan visual spasial. Analisis data menggunakan analisis kuantitatif dan kualitatif. Data kuantitatif diperoleh dengan 
menghitung skor persentase peningkatan pada tiap siklusnya. Sedangkan data kualitatif diperoleh dari pengolahan data miles dan hubberman dengan menganalisis catatan lapangan, catatan dokumentasi, catatan wawancara dan data pemantau tindakan.

\section{Perencanaan dan Pelaksanaan}

\section{Tindakan}

Penelitian ini menggunakan metode deisain penelitian tindakan model Kemmis \& Taggart dengan langkah sebagai berikut: 1) perencanaan (planning); 2) tindakan (acting); 3) pengamatan (observing); dan 4) refleksi (reflecting). Hubungan antara komponen tersebut menunjukkan sebuah siklus atau kegiatan berulang.

Berdasarkan refleksi, peneliti mendapatkan peningkatan hasil intervensi tindakan dan memungkinkan untuk melakukan perencanaan tindakan lanjutan dalam siklus selanjutnya. Adapun tahapan yang dilakukan :

1) Perencanaan : Merencanakan kegiatan bermain yang dapat mengembangkan kecerdasan visual spasial dengan melakukan kegiatan bermain mind mapping, Menyiapkan alat, bahan dan media yang akan digunakan, menyiapkan alat dokumentasi dan instrument yang akan digunakan.

2) Tindakan dan pengamatan: Melaksanakan kegiatan bermain mind mapping dan melakukan pengamatan dengan mencatat pelaksanaan kegiatan untuk melihat proses keberhasilan pembelajaran

3) Refleksi : Melakukan evaluasi dan membahas hasil evaluasi tersebut dengan kolaborator mengenai kegiatan yang dilakukan dan hasil pencapaian yang didapat anak serta memperbaiki kekurangan pada pelaksanaan kegiatan bermain mind mapping .

\section{Kriteria keberhasilan}

Kriteria keberhasilan dari penelitian ini adalah apabila terjadi peningkatan kecerdasan visual spasial pada kelompok Raudhatul Athfaal Mardhati Makassar, baik dari refleksi dalam data pemantauan tindakan maupun berdasarkan data hasil penelitian. 
Adanya persamaan persepsi bahwa dengan $71 \%$ dapat dijadikan dasar sebagai kriteria keberhasilan tindakan yang dikategorikan baik. Adapun penentuan rata-rata tersebut juga sesuai dengan hasil kesepakatan antara peneliti dan kolaborator menetapkan skor peningkatan sebesar persentase $75 \%$.

\section{Teknik pengumpulan data}

Jenis instrumen pengumpulan data yang digunakan pada penelitian ini adalah lembar pengamatan (observasi), catatan lapangan, dokumentasi, catatan wawancara dan tes tertulis. Lembar instrumen pengamatan sebelum digunakan telah dilakukan validasi pakar untuk melihat kesesuaian dan ketepatan instrumen.

\section{Teknik Analisis Data}

Data yang diperoleh dari penelitian ini mencakup dua jenis data, sesuai dengan tuntutan penelitian tindakan kelas, yaitu data kualitatif dan data kuantitatif. Data yang bersifat kualitatif dengan cara menganalisis data dari hasil observasi, tes kecerdasan, catatan lapangan, catatan dokumentasi dan catatan wawancara selama penelitian.

Data-data tersebut kemudian dianalisis dengan analisis kualitatif yang dapat dilakukan dengan reduksi data, display dan kesimpulan. Hal tersebut senada dengan pendapat yang diungkapkan oleh Miles dan Huberman bahwa, secara umum analisis data kualitatif yang dilakukan terdiri dari 3 tahap: (1) Reduksi data, (2) Paparan display data, (3) Kesimpulan.

Data yang bersifat kuantitatif dianalisis dengan analisis statistik deskpritif yaitu dilakukan dengan mencari rata-rata beserta presentasenya. Teknik deskriptif untuk menggambarkan karakteristik distribusi skor masing-masing responden misalnya mencari persentase pencapaian skor dan lainlain. (Arikunto,Suhardjono,Supardi, 2006:131).

\section{Hasil Dan Pembahasan \\ Deskripsi hasil temuan}

Berdasarkan hasil analisis data kuantitatif diperoleh persentase total kenaikan hasil observasi kecerdasan visual spasial dari pra siklus hingga 
pada siklus II sebesar 39,03\%. Pada pra siklus diperoleh persentase sebesar 49,25\%. Pada siklus I diperoleh persentase sebesar $75,15 \%$. Pada siklus II diperoleh persentase sebesar $88,28 \%$. Hasil tersebut dapat menunjukkan kesesuaian dengan hipotesis tindakan yaitu terjadi persentase kenaikan berdasarkan penelitian Mills maka hipotesis diterima. Berikut hasil analisis ratarata kelas yang terangkum dalam data tabel dan grafik :

\begin{tabular}{|c|c|c|}
\hline Pra Siklus & Siklus 1 & Siklus 2 \\
\hline $49.25 \%$ & $\mathbf{7 5 . 1 5 \%}$ & $\mathbf{8 8 . 2 8 \%}$ \\
\hline
\end{tabular}

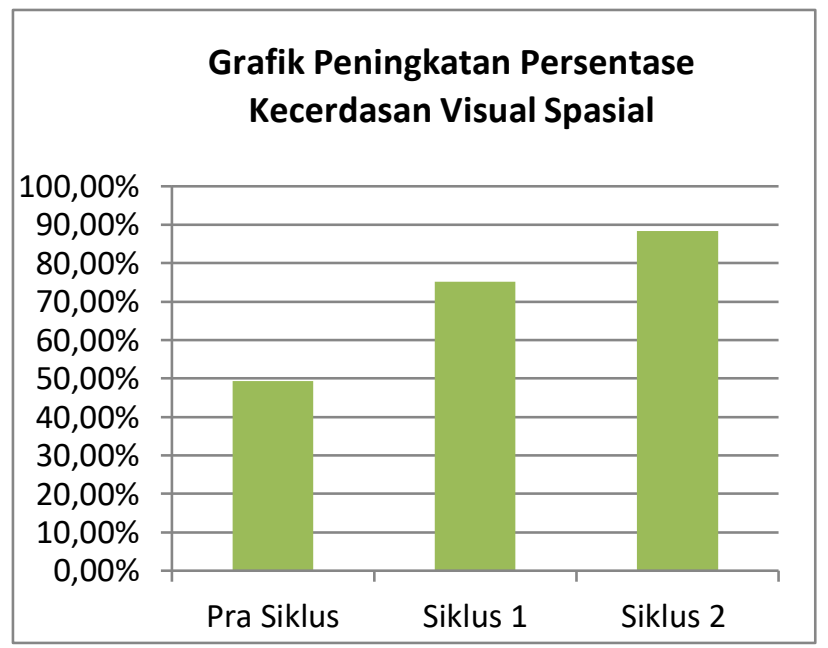

\section{Pembahasan}

Observasi hasil tindakan yang dilakukan selama pelaksanaan sangat diperlukan dalam melakukan analisis data secara kuantitatif dan kualitatif. Secara kuantitatif, berdasarkan pengamatan yang dilakukan pada siklus 1 dan siklus 2, diperoleh persentase total kenaikan hasil observasi kecerdasan visual spasial dari pra siklus hingga pada siklus II sebesar 39,03\%. Pada pra siklus diperoleh persentase sebesar 49,25\%. Pada siklus I diperoleh persentase sebesar 75,15\%. Pada siklus II diperoleh persentase sebesar 88,28\%. Hasil tersebut dapat menunjukkan kesesuaian dengan hipotesis tindakan yaitu terjadi persentase kenaikan berdasarkan penelitian Mills maka hipotesis diterima. Berdasarkan hal tersebut, melalui penggunaan kegiatan bermain mind mapping dapat meningkatkan kecerdasan visual spasial anak usia 5-6 tahun 
pada kelompok RA Mardhati. Hasil di atas didukung teori yang dikemukakan oleh Olivia (2008:8) yang menjelaskan mengenai mind mapping mempunyai banyak manfaat dalam penggunaannya, khususnya bagi anak yaitu (1) dapat membantu untuk berkonsentrasi; (2) meningkatkan kecerdasan visual spasial; (3) melatih kemampuan berpikir kritis dan komunikasi; (4) membantu mendapatkan atau memunculkan ide; serta membantu menggunakan kedua belahan otak yang membuat seseorang ingin selalu belajar. Salah satu manfaat mind mapping yang dijelaskan di atas yakni dapat meningkatkan kecerdasan visual spasial, hal tersebut sesuai dengan hasil penelitian yang telah dilakukan dan memperoleh hasil skoring secara kuantitatif yang menunjukkan peningkatan kecerdasan visual anak yang berkembang dengan baik, maka dapat disimpulkan bahwasanya penggunaan media mind mapping yang dilakukan pada dua kali siklus dalam penelitian ini menunjukkan manfaat yang baik khususnya bagi kecerdasan visual spasial anak. Hasil analisis data kualitatif membuktikan bahwa pemberian tindakan kegiatan bermain mind mapping mampu meningkatkan kecerdasan visual spasial anak. Anak telah mampu mempersepsi bentuk objek visual, anak mulai peka terhadap konsep objek visual yakni anak mampu memahami bentuk-bentuk simbol huruf dan simbol angka, bentuk garis, mengenali warna, mengenali jenis gambar dan anak mulai memahami persamaan serta perbedaan objek visual. Peningkatan tersebut dinyatakan signifikan. Hasil tersebut didukung oleh teori Armstrong (Tadkiroatun, 2008:49) yang mengemukakan bahwa cara belajar anak yang mampu meningkatkan kecerdasan visual spasialnya yakni dapat dilakukan melalui teknik dalam hal mencermati bentuk, mewarnai, mengkombinasikan warna-warna, bermain imajinasi, memetakan pikiran, menggambar dan menyusun sesuatu benda.

Selain itu, hasil analisis data kualitatif dari penelitian ini didukung pula oleh teori Sonawat dan Gogri (2008:62) menjelaskan mengenai 
unsur dari kecerdasan visual spasial yaitu diskriminasi visual yang merupakan keterampilan membedakan dua atau lebih bentuk seperti objek-objek, kata-kata atau huruf-huruf. Kemampuan visual ini meliputi pemahaman arah, mengenali kesamaan dan perbedaan, mengidentifikasi warna-warna, bentuk-bentuk, dan kata-kata.

Dari teori-teori diatas dapat ditarik kesimpulan yakni melalui kegiatan bermain mind mapping ini dapat membantu anak dalam mengenali bentuk-bentuk seperti bentuk huruf, angka, membentuk garis, mengenali kesamaan dan perbedaan objek. Selain itu anak juga belajar mengenali warna, mengenali jenis gambar, melakukan aktivitas mewarnai dan aktivitas menggambar.

Penggunaan kegiatan bermain mind mapping dapat melibatkan anak secara aktif dalam proses pembelajaran. Ketika anak-anak melakukan aktivitas tersebut, maka akan memberi kesempatan bagi anak dalam melatih kreativitasnya, melatih daya imajinasi, dan mengasah kemampuan otak kanan anak. Selain itu, penggunaan kegiatan bermain mind mapping mampu menjadi salah satu media bermain dalam proses pembelajaran bagi anak usia dini. Sebab dalam media mind mapping terdiri dari unsur-unsur warna, gambar dan garis yang menambah daya tarik bagi anak dan akan memberi kesempatan bagi anak untuk mengenali objek-objek visual tersebut.

Selain itu aktivitas bermain mind mapping termasuk salah satu aktivitas yang mampu menstimulasi pengembangan kecerdasan visual spasial. Hal ini serupa dengan yang dinyatakan Chatib dan Alamsyah bahwa menggunakan gambar sebagai alat bantu mengingat atau mendapat informasi. Selain itu, lebih lanjut dijelaskan oleh Chatib dan Alamsyah (2012:50) bahwa strategi dalam mengajar peserta didik yang memiliki kecerdasan visual yaitu dengan memberikan visualisasi, simbol grafis, dan mind mapping (gambar peta pikiran). Anak dengan kecerdasan visual akan mengumpulkan ide-ide berdasarkan visualisasi. Mereka lebih berpikir konseptual (holistik) untuk memahami sesuatu karena 
kemampuan melihat kedalam pikiran mereka akan membuat mereka pandai memecahkan masalah atau berkreasi, hal ini menunjukkan pemberian atau penyajian gambar akan membantu menstimulasi kecerdasan visual spasial. Selain pemberian media crayon, juga diberikan media cat lukis pada siklus kedua.

Perbedaan pemberian tindakan pada siklus pertama dan siklus kedua yakni berbeda dari penyajian media utama berupa penggunaan cat lukis pada kegiatan bermain mind mapping yang ditambahkan pada siklus kedua setelah diadakan perbaikan pemberian tindakan ini, membawa dampak positif yakni anak jadi lebih bersemangat dan semakin mengasah kreativitasnya dalam membuat bentuk objek visual melalui mind mapping. Aktivitas ini melatih imajinasi anak, sehingga anak mampu mengeksplore hal-hal yang ada dalam pikirannya.Hal ini tentunya dapat bermanfaat bagi anak untuk lebih mengasah otak kanannya.
Berdasarkan hasil analisis kuantitatif terlihat bahwa, pada pra siklus hingga ke siklus kedua, anak yang memperoleh skor tertinggi diperoleh oleh MF. Beberapa anak lainnya juga ada yang masuk dalam skor tertinggi yakni RF, SHR dan FA. Namun, MF memiliki skor yang mendominasi dari seluruh temantemannya. Adapun yang memperoleh skor terendah didominasi oleh RA dari pra siklus hingga siklus kedua, beberapa anak lainnya yang tergolong rendah juga adalah MR dan RT. Hal ini dapat dipengaruhi oleh faktor internal dan eksternal diantaranya yaitu faktor bawaan atau keturunan, faktor minat dan pembawaan yang khas dan faktor lingkungan.

Pada perolehan persentase skor tertinggi oleh MF dimungkinkan dipengaruhi oleh faktor-faktor pendukung tersebut di atas. Berdasarkan faktor keturunan, seperti belum dapat dinyatakan sebagai pendukung utama namun jika kita melihat latar belakang keluarga, MF berasal dari keluarga yang berpendidikan, ayahnya berprofesi sebagai karyawan swasta 
lulusan S1, ibunya adalah seorang guru yang berlatar belakang S1. Jika dilihat dari faktor minat, $\mathrm{MF}$ memang memiliki minat atau ketertarikan yang besar terhadap aktivitas yang berkaitan dengan gambar (berdasarkan observasi selama penelitian). Menurut guru, MF adalah salah satu anak yang memiliki kreativitas yang baik. Orang tua MF memang mendukung dan memfasilitasi minat atau kesukaan MF melalui aktivitas menggambar, selain itu memberikan fasilitas pembelajaran yang lain di rumah seperti stimulasi pengenalan huruf, pengenalan angka, pengenalan jenis warna dan gambar. MF juga nampak semangat dan antusias saat melakukan kegiatan bermain mind mapping.

Pada perolehan prosentase skor terendah oleh RA di siklus 1 dan siklus 2, dimungkinkan dipengaruhi oleh faktor-faktor pendukung tersebut di atas seperti halnya MF, namun berbeda pada kondisinya. Berdasarkan faktor keturunan, seperti belum dapat dinyatakan sebagai pendukung utama namun jika kita melihat latar belakang keluarga, RA berasal dari keluarga yang cukup berpendidikan, ayahnya berprofesi sebagai PNS dan ibunya sebagai karyawan swasta lulusan S1. Jika dilihat dari faktor minat, RA memang kurang memiliki minat atau ketertarikan melalui gambar atau mewarnai. RA cenderung cepat bosan dan mudah menyerah ketika tidak bisa melakukannya. Jika dilihat dari faktor lingkungan khususnya pada lingkungan di rumah RA, berdasarkan wawancara dengan orang tua RA. Peneliti mendapatkan informasi bahwa RA lebih suka bermain game atau bermain-main di luar rumah bersama temannya. Orangtuanya juga jarang menstimulasi RA untuk meningkatkan kemampuannya, disebabkan oleh kesibukan orangtua yang bekerja di luar rumah. Hanya sesekali saja mendampingi RA jika belajar di rumah. Jika dilihat dari faktor kematangan, usia RA memang lebih muda dibanding usia rata-rata dikelasnya.

Perbedaan perolehan prosentase skor yang bervariatif dapat saja dikarenakan gaya belajar 
anak yang berbeda-beda dan selalu dinamis. Mengetahui gaya belajar dan belajar dengan gaya belajar yang sesuai akan lebih memudahkan meningkatkan kecerdasan atau prestasi anak karena menurut Bobbi DePorter dan Mike Hernacki (2001:112) gaya belajar merupakan suatu kombinasi bagaimana seseorang menyerap, dan kemudian mengatur serta mengolah informasi. Gaya belajar bukan hanya berupa aspek ketika menghadapi informasi, melihat, mendengar, menulis dan berkata tetapi juga aspek pemrosesan informasi secara global melalui otak kiri-otak kanan, aspek lain adalah ketika merespon sesuatu atas lingkungan belajar yang diserap secara abstrak dan konkret. Di RA Mardhati masing-masing anak memiliki gaya belajar yang berbeda. Mungkin saja anak yang memperoleh prosentase skor yang tergolong rendah atau biasa saja dikarenakan gaya belajarnya kinestetik atau audio sehingga kegiatan bermain mind mapping yang diberikan kurang sesuai dengan gaya belajarnya sehingga sebaiknya pemberian tindakan mind mapping juga diimbangi dengan kegiatan pendamping berimbang dengan gaya belajar yang dimilik anak.

Selain gaya belajar, faktor kecerdasaan atau bakat bawaan yang berbeda tiap anak juga mempengaruhi perolehan persentase skor yang beragam. Anak yang sudah memiliki atau lebih dominan kecerdasan visual spasialnya akan lebih mudah meningkat dibanding anak yang lebih dominan kecerdasan lainnya (linguistic/bahasa, matematika logika, kinestetik dan sebagainya) karena setiap orang memiliki beberapa kecerdasan dalam tingkat yang berbeda-beda. Hal tersebut seperti yang diungkapkan Gardner (Armstrong, 2004:25) tentang konsep dasar kecerdasan jamak yaitu: 1. Setiap orang memiliki semua (delapan) kecerdasan, 2. Manusia mempunyai kemampuan meningkatkan dan memperkuat kecerdasannya, 3 . Kecerdasan biasanya bekerja sama, kecerdasan saling berkaitan dalam satu rangkaian. 4. Ada banyak cara untuk menjadi cerdas dalam setiap kategori, misalnya seseorang yang cerdas linguistik mungkin tidak 
pandai menulis, tetapi pandai bercerita dan berbicara. Hal tersebut diatas dapat mempengaruhi pencapaian persentase skor pada tiap anaknya.

Berdasarkan uraian di atas dapat dikatakan bahwa dengan penggunaan kegiatan mind mapping dapat membantu anak dalam meningkatkan kecerdasan visual spasialnya terkhusus dalam memahami bentuk-bentuk simbol, warna, dan jenis gambar. Selain itu, kegiatan bercerita juga dapat membantu anak dalam melatih daya imajinasi dan kreativitasnya. Indikator yang dijadikan acuan dalam penelitian ini mengalami peningkatan selama 13 kali pertemuan dalam dua siklus. Hal ini dapat dilihat pada indikator yang berhubungan dengan kecerdasan visual spasial pada anak.

Hal tersebut, dapat dinyatakan bahwa penggunaan kegiatan bermain mind mapping tidak hanya meningkatkan kecerdasan visual spasial anak tetapi juga dapat memberikan pengalaman yang menyenangkan dalam proses pembelajaran.

\section{Kesimpulan}

Kesimpulan penelitian ini adalah : (1) Rangkaian proses pembelajaran melalui kegiatan bermain mind mapping meliputi tahap pembukaan atau awal, tahap inti dan tahap akhir atau penutup. Kegiatan bermain mind mapping dengan dua media utama yakni media yang menggunakan peralatan crayon dan peralatan lukis. Selain itu, ada media pendukung pula diantaranya menggunakan kartu gambar huruf dan kartu angka, poster bergambar (huruf dan angka) dan bentuk-bentuk gambar. (2) Kegiatan bermain mind mapping dapat meningkatkan kecerdasan visual spasial siswa kelompok RA Mardhati Kota Makassar karena bermain mind mapping dapat menghadirkan suasana belajar yang menyenangkan bagi anak sehingga anak belajar dengan metode yang bervariasi, membuat anak bebas bereksplorasi, berimajinasi dan mengasah kreativitas yang berkaitan dengan aspek-aspek kecerdasan visual spasial. 


\section{Implikasi}

1. Aktivitas kegiatan bermain mind mapping yang diberikan bertujuan untuk meningkatkan kecerdasan visual spasial anak sehingga membantu anak untuk semakin mengembangkan dan mematangkan kecerdasan visual spasial anak dalam aspek kemampuan mempersepsikan objek visual, kepekaan terhadap konsep objek visual dan aspek pada kemampuan mengenali persamaan dan perbedaan objek visual. Konsep kegiatan melalui media mind mapping yang disajikan kepada anak memberi suasana belajar yang menyenangkan bagi anak sehingga anak belajar tanpa tekanan, membuat anak bebas bereksplorasi, berimajinasi dan mengasah kreativitasnya masingmasing.

2. Kegiatan bermain mind mapping menjadikan anak lebih kreatif, dan aktif bereksplorasi dalam mempersepsikan dan mengenali bentuk-bentuk objek simbol huruf, simbol angka, jenis warna dan gambar sehingga kecerdasan visual spasial anak meningkat dengan kondisi pembelajaran yang menyenangkan dan sesuai dengan karakteristik anak.

3. Penerapan kegiatan bermain mind mapping pada anak ini perlu memperhatikan beberapa hal, yakni mengenai waktu pelaksanaan yang sesuai. Mempersiapkan waktu yang cukup untuk melakukan pengkondisian, menyusun tema, sub tema, dan melakukan brainstorming kepada anak sekitar 10 menit. Penggunaan kegiatan mind mapping selama 25 menit serta melakukan review kegiatan yang telah dilakukan membutuhkan waktu sekitar 5 menit. Untuk memperoleh data yang akurat, peneliti dan kolaborator melakukan asesmen kepada anak setelah pelaksanaan tindakan atau pada akhir siklus. Dari hasil asesmen yang dilakukan, diperoleh hasil adanya peningkatan kecerdasan visual spasial melalui kegiatan bermain mind mapping. Implikasinya adalah kegiatan mind mapping dapat digunakan sebagai metode 
atau sarana dalam proses pembelajaran, khususnya sebagai pijakan awal bagi anak dalam melatih kemampuan membaca dan menulis. Hal ini merupakan salah satu langkah efektif dalam kegiatan pembelajaran.

\section{DAFTAR PUSTAKA}

Arikunto., Suhardjono., dan Supardi. Penelitian Tindakan Kelas. Jakarta : PT. Bumi Aksara, 2006.

Armstrong, Thomas. Sekolah Para Juara (Menerapkan Multiple Intelegences di Dunia Pendidikan), Penerjemah : Yudhi Murtanto. Bandung : Penerbit Kaifa, 2004.

Buzan,. Mind Maps at Work Cara Cemerlang Menjadi Bintang di Tempat Kerja terjemah Daniel Wirajaya. Jakarta: PT.Gramedia, 2006.

Campbell, Linda., Campbell, Bruce., dan Dickinson, Dee. Metode Praktis Pembelajaran Berbasis Multiple Intelligences terjemahan Tim Intuisi. Depok: Inisiasi Press, 2002.

Chatib, Munif \& Said, Alamsyah. Sekolah Anak-anak Juara, : Berbasis Kecerdasan Jamak dan

Pendidikan
Berkeadilan. Bandung: Penerbit Kaifa, 2012.

De Porter, Bobbi dan Hernacki, Mike. Quantum Learning (Membiasakan Belajar Nyaman dan Menyenangkan). Bandung : Penerbit Kaifa, 2001.

Jasmine, Julia. Metode Mengajar Multiple Intelligences. Bandung: Penerbit Nuansa Cendikia, 2012.

Olivia, Femi. Membantu Anak Punya Ingatan Super. Jakarta : Elex Media Komputindo, 2008. dan Ariani, Lita. Belajar Membaca yang Menyenangkan untuk Anak Usia Dini. Jakarta : PT Elex Media Komputindo, 2009.

Prasetyo, J.J. Reza \& Andriani, Yeny. Melatih 8 Kecerdasan Majemuk Pada Anak dan Dewasa. (Yogyakarta: Penerbit ANDI, 2009)

Sonawat, Reeta \& Gogri, Purvi. Multiple Intelligences For Preschool Children. Mumbai : Multi-tech Publishing, 2008.

Tadkiroatun, Musfiroh. Cerdas Melalui Bermain, Cara Mengasah Multiple Intelligences pada Anak Sejak Usia Dini. Jakarta: PT. Grasindo, 2008. 